\title{
More P450s Are Involved in Secondary Metabolite Biosynthesis in Streptomyces Compared to Bacillus, Cyanobacteria, and Mycobacterium
}

\author{
Fanele Cabangile Mnguni ${ }^{1}$, Tiara Padayachee ${ }^{1}{ }^{(\mathbb{C}}$, Wanping Chen ${ }^{2}{ }^{(}$, Dominik Gront ${ }^{3}{ }^{(1)}$, \\ Jae-Hyuk Yu ${ }^{4,5}$, David R. Nelson ${ }^{6, * \mathbb{D}}$ and Khajamohiddin Syed ${ }^{1, * \mathbb{D}}$ \\ 1 Department of Biochemistry and Microbiology, Faculty of Science and Agriculture, University of Zululand, \\ KwaDlangezwa 3886, South Africa; fanelemngun@gmail.com (F.C.M.); teez07padayachee@gmail.com (T.P.) \\ 2 Department of Molecular Microbiology and Genetics, University of Göttingen, 37077 Göttingen, Germany; \\ chenwanping1@foxmail.com \\ 3 Faculty of Chemistry, Biological and Chemical Research Center, University of Warsaw, Pasteura 1, \\ 02-093 Warsaw, Poland; dgront@gmail.com \\ 4 Department of Bacteriology, University of Wisconsin-Madison, 3155 MSB, 1550 Linden Drive, \\ Madison, WI 53706, USA; jyu1@wisc.edu \\ 5 Department of Systems Biotechnology, Konkuk University, Seoul 05029, Korea \\ 6 Department of Microbiology, Immunology and Biochemistry, University of Tennessee Health Science Center, \\ Memphis, TN 38163, USA \\ * Correspondence: drnelson1@gmail.com (D.R.N.); khajamohiddinsyed@gmail.com (K.S.)
}

Received: 18 January 2020; Accepted: 13 February 2020; Published: 7 July 2020

\begin{abstract}
Unraveling the role of cytochrome P450 monooxygenases (CYPs/P450s), heme-thiolate proteins present in living and non-living entities, in secondary metabolite synthesis is gaining momentum. In this direction, in this study, we analyzed the genomes of 203 Streptomyces species for P450s and unraveled their association with secondary metabolism. Our analyses revealed the presence of 5460 P450s, grouped into 253 families and 698 subfamilies. The CYP107 family was found to be conserved and highly populated in Streptomyces and Bacillus species, indicating its key role in the synthesis of secondary metabolites. Streptomyces species had a higher number of P450s than Bacillus and cyanobacterial species. The average number of secondary metabolite biosynthetic gene clusters (BGCs) and the number of P450s located in BGCs were higher in Streptomyces species than in Bacillus, mycobacterial, and cyanobacterial species, corroborating the superior capacity of Streptomyces species for generating diverse secondary metabolites. Functional analysis via data mining confirmed that many Streptomyces P450s are involved in the biosynthesis of secondary metabolites. This study was the first of its kind to conduct a comparative analysis of P450s in such a large number (203) of Streptomyces species, revealing the P450s' association with secondary metabolite synthesis in Streptomyces species. Future studies should include the selection of Streptomyces species with a higher number of P450s and BGCs and explore the biotechnological value of secondary metabolites they produce.
\end{abstract}

Keywords: Streptomyces; Mycobacterium; Bacillus; Cyanobacteria; cytochrome P450 monooxygenases; secondary metabolites; biosynthetic gene clusters; terpenes; polyketides; P450 blooming; non-ribosomal peptides

\section{Introduction}

Cytochrome $\mathrm{P} 450$ monooxygenases (CYPs/P450s) are biotechnologically valuable enzymes [1]. P450s have heme (protoporphyrin IX), an iron(III)-containing porphyrin, as a prosthetic group in their 
structure [2]. Because of the presence of this prosthetic group, these enzymes absorb wavelengths at $450 \mathrm{~nm}$; thus, the name P450s has been assigned to these proteins [3-6]. Since their identification, a large number of P450s have been identified in almost all living organisms [7] and, surprisingly, in non-living entities as well [8]. The regio- and stereo-specific catalytic nature of these enzymes makes them essential for the survival of some organisms, and these enzymes are thus good drug targets in the case of pathogenic organisms [9-13]. Application of these enzymes in all fields of research continues, and excellent success has been achieved in using them for the production of substances valuable to humans or as drug targets or in drug metabolism, as reported previously [1]. One of the applications of P450s currently being explored is their role in the production of secondary metabolites, compounds with potential biotechnological value, owing to their stereo- and regio-specific enzymatic activity, which contributes to the diversity of secondary metabolites [14-16].

Unlike other enzymes, P450 enzymes have a typical nomenclature system established by the International P450 Nomenclature Committee [17-19]. According to the committee's rules, P450s begin with the prefix "CYP" for cytochrome P450 monooxygenase, followed by an Arabic numeral which designates the family, a capital letter designating the subfamily, and an Arabic numeral designating the individual P450 in a family. The annotation of P450s (assigning family and subfamily) follows a rule that all P450s with $>40 \%$ identity belong to the same family and all P450s with $>55 \%$ identity belong to the same subfamily [17-19]. Worldwide, researchers follow this P450 nomenclature system. The nomenclature of P450s is also be verified by phylogenetic analysis to enable their correct annotation, as phylogenetic-based annotation could detect similarity cues beyond a simple percentage identity cutoff, as mentioned elsewhere [20].

The continued genomic rush has resulted in genome sequencing of a large number of species belonging to all biological kingdoms. P450s in the newly sequenced species need to be annotated as per the International P450 Nomenclature Committee rules [17-19] to enable researchers to use the same names for functional and evolutionary analysis of P450s. For this reason, large numbers of P450s have recently been annotated in bacterial species belonging to the genera Mycobacterium [21], Bacillus [22], Streptomyces [20], and Cyanobacteria [23]. These studies have revealed numerous P450s involved in the synthesis of different types of secondary metabolites. This type of in silico study is highly important for identifying unique P450s that can be drug-targeted and for P450 evolutionary analysis, as the P450 profiles in species have been found to be characteristic of species' lifestyle [11,20,22,24-27].

Among bacterial species, Streptomyces species are well-known for producing over two-thirds of the clinically useful antibiotics in the world [28]. Because of this importance, Streptomyces species have been subjected to exhaustive secondary metabolite production studies $[29,30]$. Streptomyces P450s play a key role in the production of different secondary metabolites; their contribution to secondary metabolite diversity and applications in drug metabolism have been reviewed extensively [15,16,31-33]. In the latest study, comprehensive comparative analysis of P450 and secondary metabolite biosynthetic gene clusters (BGCs) in 48 Streptomyces species was elucidated [20]. The study revealed the presence of novel P450s in Streptomyces species and numerous P450s forming parts of secondary metabolite BGCs [20]. The study results indicated that lifestyle or ecological niches play a key role in the evolution of P450 profiles in species belonging to the genera Streptomyces and Mycobacterium [20].

To date, a large number of Streptomyces species genomes have been sequenced and are available for public use. This provided an opportunity to annotate P450s in these species to analyze and compare their profiles among different bacterial species, including the identification and comparative analysis of P450s involved in the production of secondary metabolites. This study thus aimed to perform genome data mining, annotation, and phylogenetic analysis of P450s in 155 newly available Streptomyces species genomes. It also included the identification and comparative analysis of P450s that are parts of secondary metabolite BGCs among bacterial species belonging to the genera Streptomyces, Bacillus, Mycobacterium, and Cyanobacteria, as the species belonging to these genera are known to have P450s and to produce secondary metabolites. 


\section{Results and Discussion}

\subsection{Streptomyces Species Have Large Number of P450s}

Genome-wide data mining and annotation of P450s in 203 Streptomyces species (Supplementary Table S1) revealed the presence of 5460 P450s in their genomes (Figure 1, Table 1, and Supplementary Dataset 1). The P450 count in the Streptomyces species ranged from 10 to 69 P450s, with an average of 27 P450s. Apart from the complete P450 sequences, pseudo-P450s (6 hit proteins), P450-fragments (114 hit proteins), P450-derived glycosyltransferase activator proteins (22 hit proteins), and P450 false-positive hits ( 2 hit proteins) were also found in some Streptomyces species (Supplementary Table S2). The presence of these types of $\mathrm{P} 450$ hit proteins in species is common and, because of the nature of these proteins, they were not included in the study for further analysis. Among Streptomyces species, Streptomyces albulus ZPM was found to have the highest number of P450s in its genome (69 P450s) followed by S. clavuligerus (65 P450s); the lowest number of P450s was found in Streptomyces sp. CNT372 and S. somaliensis DSM 40738 (10 P450s each) (Figure 1 and Table 1). Analysis of the most prevalent number of P450s revealed that 19 P450s was the prevalent number in Streptomyces species (Table 1). The average number of P450s in Streptomyces species was found to be higher than in Bacillus species [22] and cyanobacterial species [23], and almost the same as in mycobacterial species [21] (Table 2). A point to be noted is that the number of species greatly influences the average number of P450s and, thus, the higher the number of species in the analysis, the better and more accurate the results, as mentioned elsewhere $[20,23]$. This is the reason Streptomyces species showed a slightly lower average number of P450s in their genomes compared to mycobacterial species, since only 60 species were employed in the study [21]. Thus, future annotation of P450s in more mycobacterial species will provide accurate insights into this aspect.

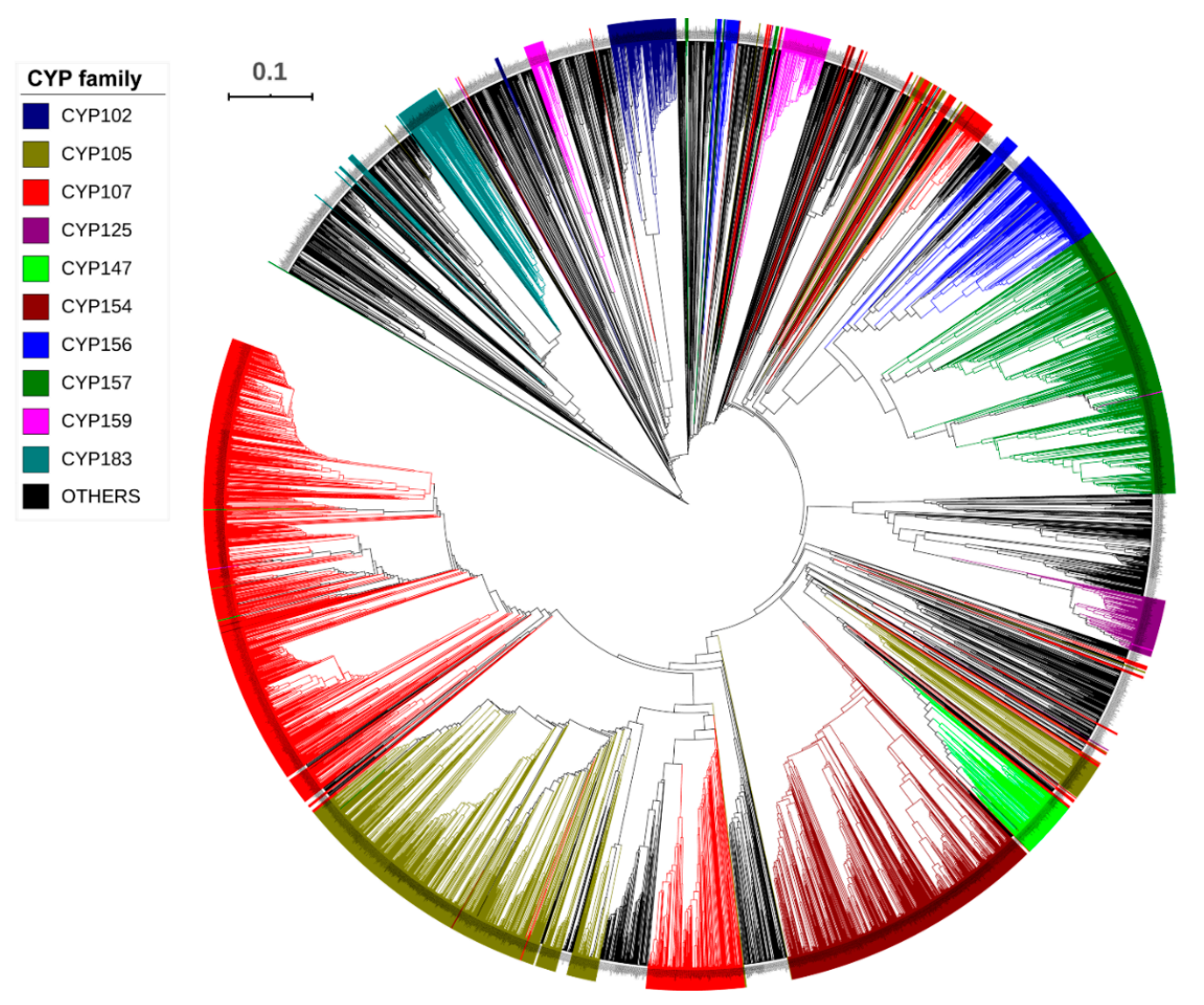

Figure 1. Phylogenetic analysis of Streptomyces P450s. In total, 5460 P450s were used to construct the tree and the dominant P450 families are highlighted in different colors and indicated in the figure. A high-resolution phylogenetic tree is provided in Supplementary Dataset 2. 
Table 1. Genome-wide data mining and annotation of P450s in 203 Streptomyces species.

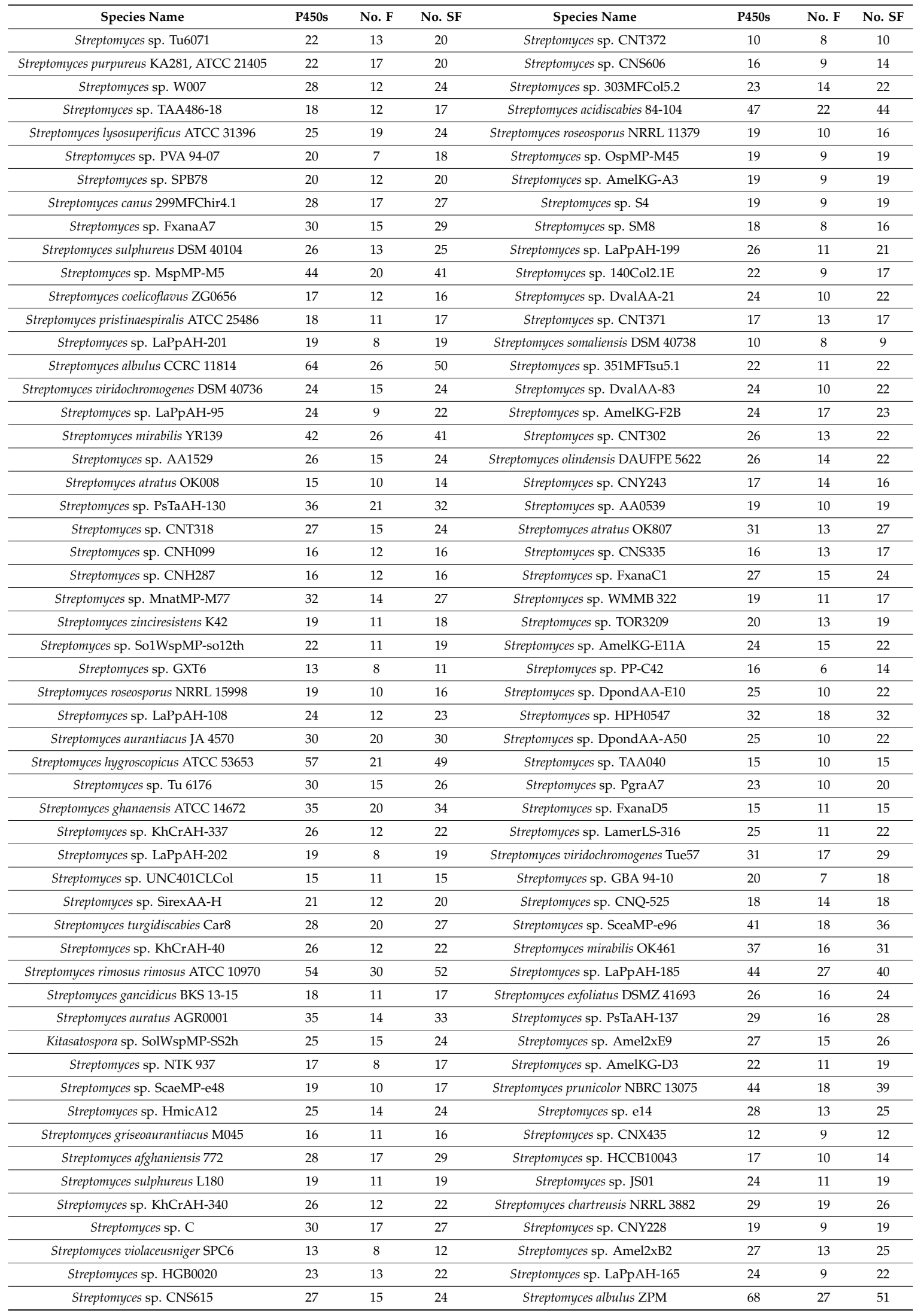


Table 1. Cont.

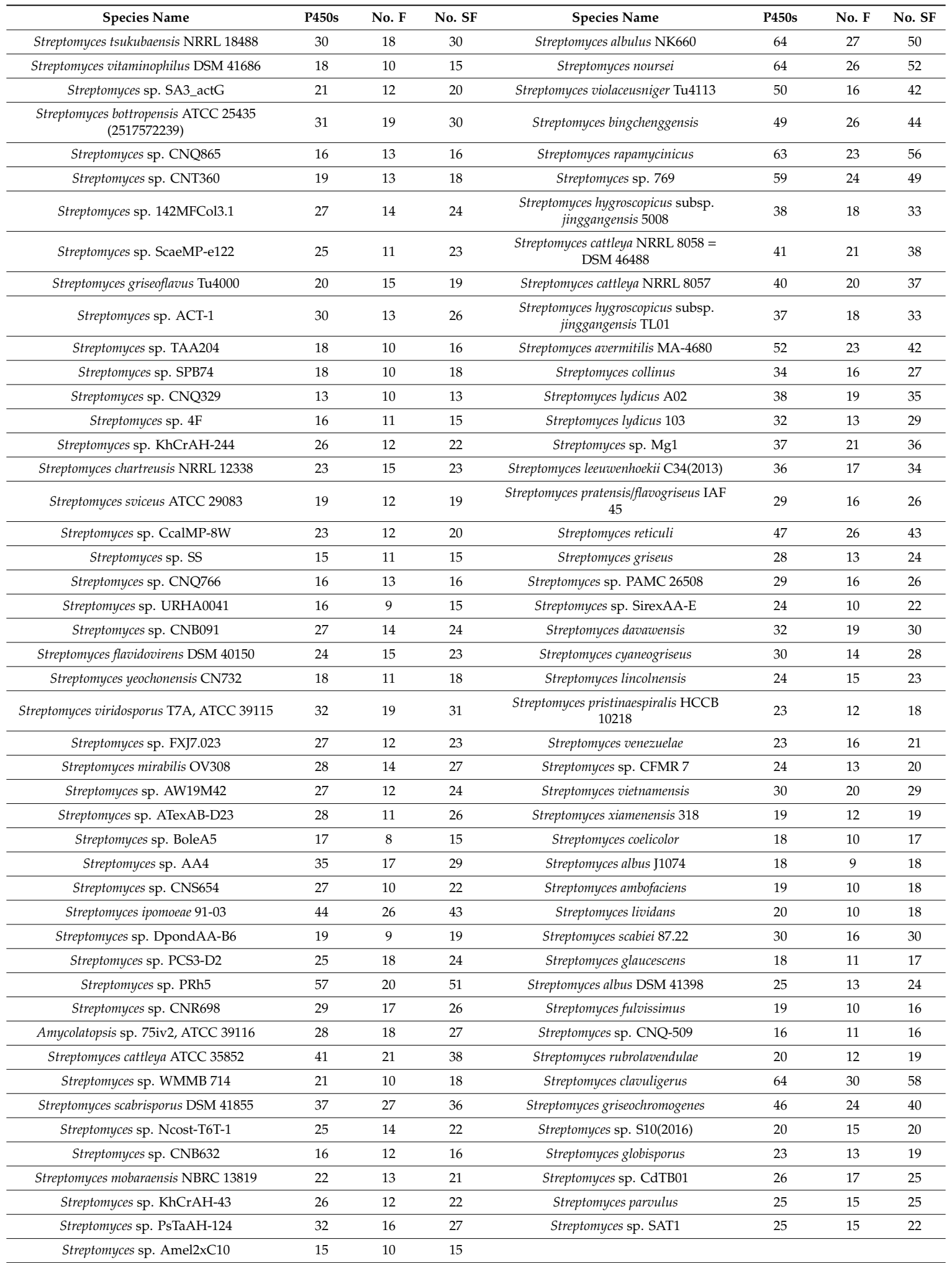

Abbreviations: No. F: number of P450 families; No. SF: number of P450 subfamilies. 
Table 2. Comparative analysis of key features of P450s in different bacterial species.

\begin{tabular}{ccccc}
\hline & Streptomyces Species & Mycobacterial Species & Bacillus Species & Cyanobacterial Species \\
\hline Total No. of species analyzed & 203 & 60 & 128 & 114 \\
\hline No. of P450s & 5460 & 1784 & 507 & 341 \\
\hline No. of families & 253 & 77 & 13 & 36 \\
\hline No. of subfamilies & 698 & 132 & 28 & 79 \\
\hline Dominant P450 family & CYP107 & CYP125 & CYP107 & CYP110 \\
\hline Average no. of P450s & 27 & 30 & 4 & 3 \\
\hline No. of BGCs * & 4457 & 898 & 1098 & 770 \\
\hline Average no. of BGCs & 31 & 15 & 9 & 27 \\
\hline No. of P450s part of BGCs & 1231 & 204 & 112 & 8 \\
\hline Percentage of P450s part of BGCs & 22 & 11 & 22 & {$[23]$} \\
\hline Reference & This work & {$[20,21]$} & {$[22]$} & 744 \\
\hline
\end{tabular}

Abbreviations: BGC: biosynthetic gene cluster. Symbol: *103 cyanobacterial species [23] and 144 Streptomyces species were used for BGC analysis.

\subsection{CYP107 Family Was Found to Be Dominant and Conserved in 203 Streptomyces Species}

Analysis of P450 families and subfamilies in 203 Streptomyces species revealed that 5460 P450s could be grouped into 253 P450 families and 698 P450 subfamilies (Table 2 and Supplementary Table S3). Among Streptomyces species, S. clavuligerus had the highest number of P450 families (30) and P450 subfamilies (58) in its genome (Table 1). Although S. rimosus rimosus ATCC 10970 had the same number of P450 families as S. clavuligerus, the number of subfamilies was the third highest (52 subfamilies) (Table 1). One interesting observation is that the species with the highest number of P450s did not have the highest number of P450 families, suggesting that some of the P450 families were populated (bloomed). Blooming of P450 families is common across species, and this phenomenon has been observed in different species belonging to different biological kingdoms [24,26,34-36]. Phylogenetic analysis revealed that some of the P450 families were scattered across the evolutionary tree (Figure 1). This phenomenon was also observed previously for Streptomyces species P450s, and it has been hypothesized that the phylogenetic-based annotation of P450s could be detecting similarity cues beyond a simple percentage identity cutoff [20]. Analysis of P450 families in the 155 Streptomyces species used in this study revealed the presence of 38 new P450 families, i.e., CYP1200A1, CYP1216A1, CYP1223A1, CYP1228A1, CYP1236A1, CYP1238A1, CYP1265A1, CYP1279A1, CYP1369A1, CYP1432A1, CYP1518A1, CYP1529A1, CYP1543A1, CYP1568A1, CYP159A1, CYP1607A1, CYP1658A1, CYP1759A1, CYP1810A1, CYP1832A1, CYP1866A1, CYP1896A1, CYP1920A1, CYP1929A1, CYP1931A1, CYP1940A1, CYP1941A1, CYP1943A1, CYP1972A1, CYP1984A1, CYP1994A1, CYP2076A1, CYP2080A1, CYP2134A1, CYP2180A1, CYP2349A1, CYP2427A1, and CYP2723A1. A detailed analysis of the number of new P450 families found in different Streptomyces species is presented in Supplementary Table S2.

Among the P450 families, the CYP107 family was found to be dominant, with 1235 P450s in Streptomyces species, followed by CYP105 with 684 P450s, CYP157 with 525 P450s, and CYP154 with 510 P450s (Figure 2 and Supplementary Table S3), indicating the possible blooming of these families in Streptomyces species, as observed in species belonging to different biological kingdoms [24,26,34-36]. It is interesting to note that the CYP107 family was also found to be dominant in the Bacillus species [22], indicating its dominant role in the synthesis of secondary metabolites in both the Streptomyces and Bacillus genera. An interesting pattern was observed when comparing subfamily diversity in the dominant P450 families (Figure 2, Table 3, and Supplementary Table S3). P450 families such as CYP107, CYP105, CYP183, and CYP113 had the highest diversity at the subfamily level, as numerous subfamilies were found in these families (Supplementary Table S3). This phenomenon of the highest diversity in P450 families being found in Streptomyces species is not uncommon, and this proved to be the key contributor in the production of diverse secondary metabolites in Streptomyces species compared to mycobacterial species [20]. Strong support for this argument is the fact that the CYP105 P450 family members in Streptomyces species have been shown to be involved in oxidation of numerous 
endogenous and exogenous compounds and in the generation of different secondary metabolites [32]. However, in contrast to the diversity at subfamily level for the P450 families CYP107, CYP105, CYP183, and CYP113, the rest of the dominant P450 families had single or double or triple subfamilies, indicating subfamily-level blooming in these P450 families (Table 3).

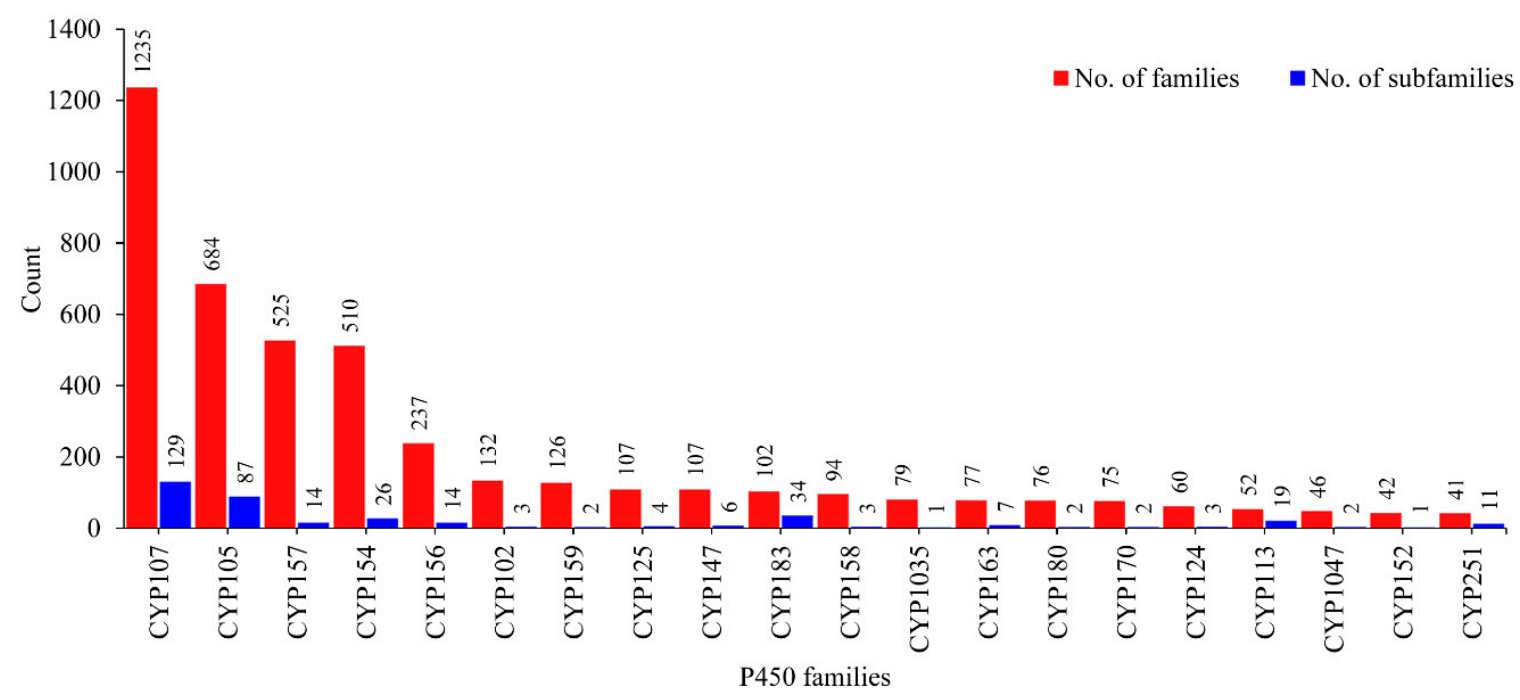

Figure 2. P450 family and subfamily analysis in 203 Streptomyces species. Only the dominant P450 families with more than 40 P450s are shown in the figure. Detailed data on P450 families and subfamilies are presented in Supplementary Table S3.

Table 3. P450 subfamily analysis in the dominant families in 203 Streptomyces species. The number of members in the dominant P450 subfamily is presented. Detailed data on different subfamilies are presented in Supplementary Table S3.

\begin{tabular}{|c|c|c|c|c|c|c|c|}
\hline \multirow{2}{*}{ P450 Family } & \multicolumn{7}{|c|}{ Dominant Subfamilies } \\
\hline & $\mathbf{A}$ & B & $\mathrm{C}$ & D & $\mathrm{E}$ & F & G \\
\hline CYP157 & 174 & & 177 & & & & \\
\hline CYP154 & 127 & & 164 & 76 & & & \\
\hline CYP156 & & 120 & & & & & \\
\hline CYP102 & & 78 & & & & & 48 \\
\hline CYP159 & 125 & & & & & & \\
\hline CYP125 & 104 & & & & & & \\
\hline CYP147 & & & & & & 73 & \\
\hline CYP158 & 91 & & & & & & \\
\hline CYP1035 & 79 & & & & & & \\
\hline CYP163 & & 50 & & & & & \\
\hline CYP180 & 54 & & & & & & \\
\hline CYP170 & 57 & & & & & & \\
\hline CYP124 & & & & & & & 50 \\
\hline CYP1047 & 43 & & & & & & \\
\hline CYP152 & & & & 42 & & & \\
\hline CYP251 & 23 & & & & & & \\
\hline
\end{tabular}


P450 family conservation analysis revealed that the CYP107 family is conserved in all 203 Streptomyces species (Figure 3 and Supplementary Dataset 3). P450 families such as CYP156, CYP105, CYP154 and CYP157 are also present in the majority of the Streptomyces species (Figure 3 and Supplementary Dataset 3).

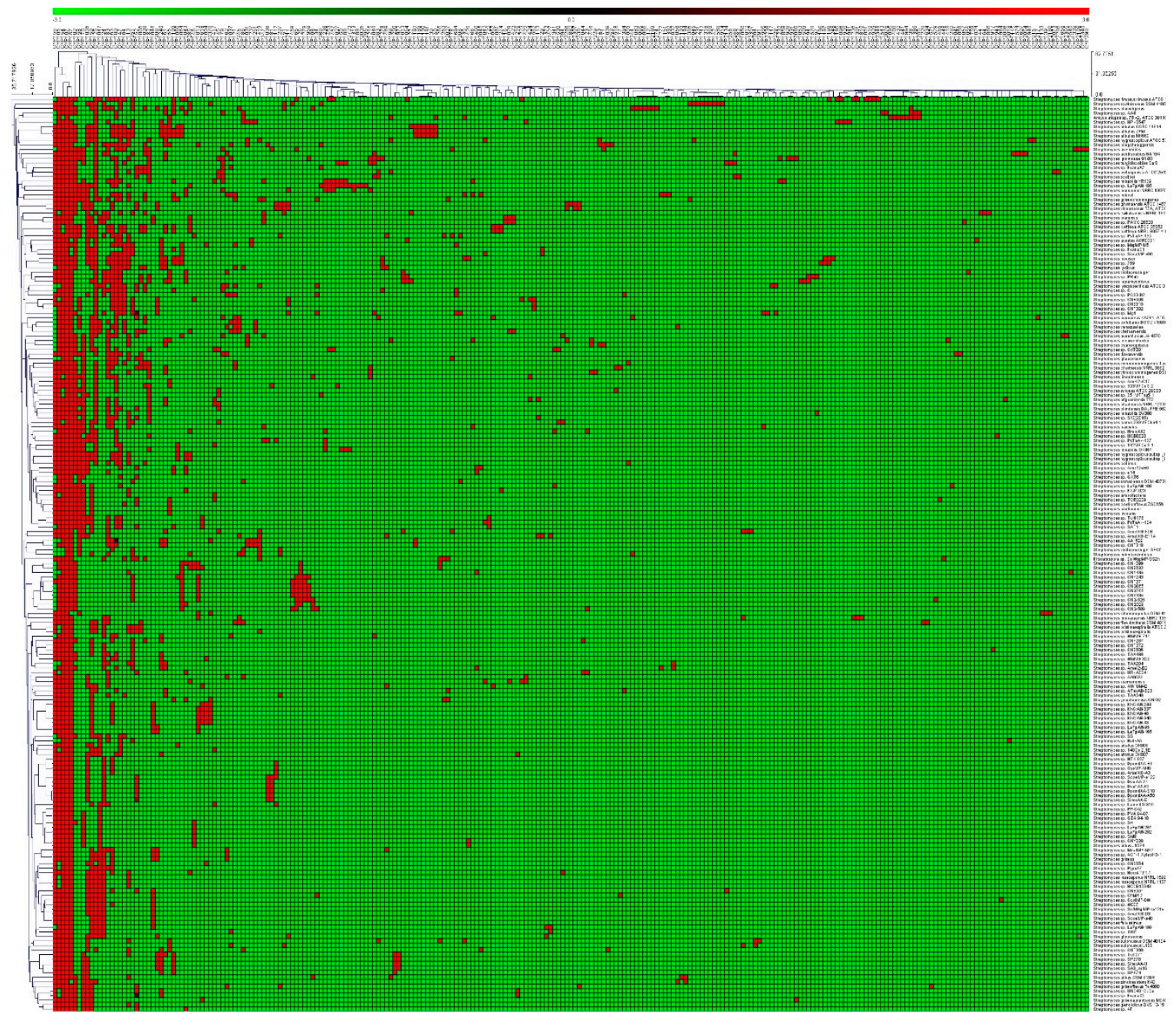

Figure 3. Heat-map of P450 family conservation analysis in Streptomyces species. In the heat-map, the presence and absence of $\mathrm{P} 450$ families are indicated in red and green colors. The horizontal axis represents $\mathrm{P} 450$ families and the vertical axis represents Streptomyces species.

\subsection{Numerous P450s Involved in Secondary Metabolite Production in Streptomyces Compared to Other Bacterial Species}

Analysis of 144 Streptomyces species' genomes revealed the presence of 4457 BGCs in their genomes (Table 2 and Supplementary Table S4). The number of BGCs found in 144 Streptomyces species was found to be higher than in mycobacterial, Bacillus, and cyanobacterial species (Table 2), indicating the superiority of the Streptomyces species in producing secondary metabolites; two-thirds of the antibiotics used in the world currently come from these species [28]. The average number of BGCs in Streptomyces species was found to be double compared to mycobacterial species and close to four times higher than that in Bacillus and cyanobacterial species (Table 2). Analysis of BGCs revealed that a large proportion of Streptomyces species' P450s are part of BGCs compared to other bacterial species; 1231 P450s in Streptomyces species compared to 112 in Bacillus species, 204 in mycobacterial species, and 27 in cyanobacterial species (Table 2). A total of 1231 P450s were found to be part of BGCs belonging to 135 P450 families (Figure 4 and Supplementary Table S5). Among 135 P450 families, P450s belonging 
to the CYP107 family were dominantly present in BGCs, followed by CYP105, CYP157, and CYP154 (Figure 4 and Supplementary Table S5). This clearly suggests that the P450 families that are bloomed in Streptomyces species are actually involved in the production of secondary metabolites. This strongly supports the proposed hypothesis that in Streptomyces species, P450s are evolved to generate secondary metabolites, thus helping these bacteria to thrive in their environment [20]. In order to assess the in silico results generated by this study, in which a large number of Streptomyces species P450s were predicted to be involved in secondary metabolite production, we performed an extensive literature review to identify Streptomyces P450s involved in the production of secondary metabolites. As shown in Table 4, a large number of $\mathrm{P} 450$ s belonging to different $\mathrm{P} 450$ families, as predicted in this study, were found to be involved in the production of different secondary metabolites. This strongly supports the notion that the P450s identified as part of different BGCs in this study produce secondary metabolites.
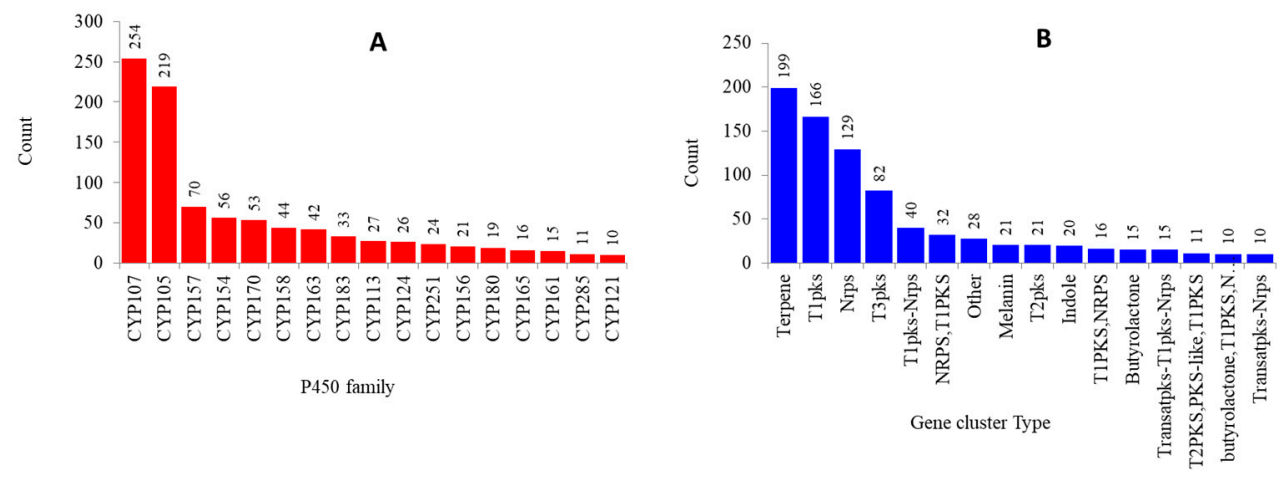

Figure 4. Analysis of P450s associated with secondary metabolite production in Streptomyces species. (A) Dominant P450 families (families with higher numbers of members) that are part of biosynthetic gene clusters (BGCs) and (B) dominant BGCs (present in higher numbers) containing P450s were presented in the figure. The numbers next to bars indicate the number of P450s in panel $\mathrm{A}$ and the number of BGCs in panel B. Detailed information is presented in Supplementary Table S5.

Analysis of P450 BGCs revealed the presence of 235 types of BGCs, where the BGC type, such as terpene, was dominant, followed by T1PKS, NRPS, and T3PKS (Figure 4 and Supplementary Table S5). A detailed analysis of P450s that are part of BGCs and types of BGCs containing P450s is presented in Supplementary Table S5. Analysis of the linkage between a particular P450 family and BGC revealed that some P450s are linked to a particular BGC (Supplementary Table S4), indicating horizontal transfer of BGCs between Streptomyces species. Streptomyces P450s such as CYP283A are linked to bacteriocin and bottromycin; CYP113K3 is linked to Bacteriocin-Nrps, CYP124G is linked to melanin, and CYP105A is linked to NRPS and butyrolactone. A point to be noted is that horizontal transfer of BGCs among different organisms is well-documented in the literature [37].

Table 4. List of Streptomyces species P450s involved in synthesis of secondary metabolites.

\begin{tabular}{cccc}
\hline P450 & Species & Function & References \\
\hline CYP158A1 & Streptomyces coelicolor A3(2) & Flaviolin biosynthesis & {$[38]$} \\
\hline CYP1048A1 & Streptomyces scabiei & Thaxtomin (phytotoxin) biosynthesis & {$[39]$} \\
\hline CYP105A1 & Streptomyces griseolus & Diterpenoids synthesis & {$[40]$} \\
\hline CYP105A3 (P450sca-2) & Streptomyces carbophilus & Pravastatin synthesis & {$[41]$} \\
\hline CYP105B28(GfsF) & Streptomyces graminofaciens & Macrolide antibiotic synthesis & {$[42,43]$} \\
\hline CYP105D6 & Streptomyces avermitilis & Filipin biosynthesis & {$[44]$} \\
\hline CYP105D7 & Streptomyces avermitilis & Filipin biosynthesis & {$[45]$} \\
\hline CYP105D8 & Streptomyces tubercidicus strain I-1529 & Avermectin oxidation & {$[32,46]$} \\
\hline
\end{tabular}


Table 4. Cont

\begin{tabular}{|c|c|c|c|}
\hline P450 & Species & Function & References \\
\hline CYP105D9 & Streptomyces sp. JP95 & Griseorhodin biosynthesis & {$[32,47]$} \\
\hline CYP105F2 & Streptomyces peucetius & Oleandomycin biosynthesis & {$[48,49]$} \\
\hline CYP105H1 & Streptomyces noursei ATCC 11455 & Nystatin biosynthesis & [32] \\
\hline CYP105H3 & Streptomyces natalensis & Pimaricin biosynthesis & {$[32,50]$} \\
\hline CYP105H4 (AmphN)! & Streptomyces nodosus & Amphotericin biosynthesis & {$[51,52]$} \\
\hline CYP105H5 & Streptomyces griseus & Candidicin biosynthesis & {$[32]$} \\
\hline CYP105K1 & Streptomyces tendae strain Tue901 & Nikkomycin biosynthesis & {$[32,53]$} \\
\hline CYP105K2 & Streptomyces ansochromogenes & Nikkomycin biosynthesis & [32] \\
\hline CYP105L1 (TylH1,orf7)! & Streptomyces fradiae & Tylosin biosynthesis & {$[54,55]$} \\
\hline CYP105L4(ChmH1)* & Streptomyces bikiniensis & Chalcomycin biosynthesis & [56] \\
\hline CYP105M1 (orf10)! & Streptomyces clavuligerus & Clavulanic acid antibiotic biosynthesis & [57] \\
\hline CYP105N1 & Streptomyces coelicolor $\mathrm{A} 3(2)$ & Coelibactin siderophore biosynthesis & {$[58,59]$} \\
\hline CYP105P1 & Streptomyces avermitilis & Filipin biosynthesis & [44] \\
\hline CYP105U1 & Streptomyces hygroscopicus & Geldanamycin biosynthesis & [60] \\
\hline CYP105V1 & Streptomyces sp. HK803 & Phoslactomycin biosynthesis & {$[32,61]$} \\
\hline CYP105AA1 & Streptomyces tubercidicus strain R922 & Avermectin oxidation & {$[32,46]$} \\
\hline CYP105AA2 & Streptomyces tubercidicus strain I-1529 & Avermectin oxidation & {$[32,46]$} \\
\hline CYP107A1 & Streptomyces peucetius & Dealkylation of 7-ethoxycoumarin & {$[62]$} \\
\hline CYP107A1 & Saccharopolyspora erythraea & Erythromycin biosynthesis & {$[63,64]$} \\
\hline CYP107B (HmtN)! & Streptomyces himastatinicus ATCC 53653 & Himastatin biosynthesis & {$[65]$} \\
\hline CYP107B (HmtN) & Streptomyces himastatinicus & Himastatin biosynthesis & [66] \\
\hline CYP107C1 & Streptomyces thermotolerans & Carbomycin biosynthesis & [67] \\
\hline CYP107E40(chmPII) * & Streptomyces bikiniensis & Chalcomycin biosynthesis & [56] \\
\hline CYP107EE2(chmPI)* & Streptomyces bikiniensis & Chalcomycin biosynthesis & [56] \\
\hline CYP107FH5(TamI)* & Streptomyces sp. 307-9 & Tirandamycin biosynthesis & {$[68,69]$} \\
\hline CYP107G1 & Streptomyces rapamycinicus & Rapamycin biosynthesis & {$[70,71]$} \\
\hline CYP107G1 (rapN)! & Streptomyces hygroscopicus & Rapamycin biosynthesis & {$[71,72]$} \\
\hline CYP107L1 & Streptomyces venezuelae & Macrolide antibioitics biosynthesis & [73] \\
\hline CYP107L59(FosK)* & Streptomyces pulveraceus & Fostriecin biosynthesis & [74] \\
\hline CYP107MD3(FosG)* & Streptomyces pulveraceus & Fostriecin biosynthesis & [74] \\
\hline CYP107W1 & Streptomyces avermitilis & Oligomycin A biosynthesis & {$[75,76]$} \\
\hline CYP112A2 & Streptomyces rapamycinicus & Rapamycin biosynthesis & {$[70,71]$} \\
\hline CYP113A1 & Saccharopolyspora erythraea & Erythromycin biosynthesis & {$[63,64]$} \\
\hline CYP113B1 (TylI)! & Streptomyces fradiae & Tylosin biosynthesis & {$[54,55]$} \\
\hline CYP113D3(HmtT)* & Streptomyces himastatinicus ATCC 53653 & Himastatin biosynthesis & [65] \\
\hline CYP113D3 (HmtT) * & Streptomyces himastatinicus & Himastatin biosynthesis & [66] \\
\hline CYP113HI (HmtS) * & Streptomyces himastatinicus & Himastatin biosynthesis & [66] \\
\hline CYP122A2 (rapJ)! & Streptomyces hygroscopicus & Rapamycin biosynthesis & {$[70,71]$} \\
\hline CYP122A3 & Streptomyces hygroscopicus & Rapamycin biosynthesis & {$[70,71]$} \\
\hline CYP122A4 (FkbD)! & Streptomyces tsukubaensis & $\begin{array}{l}\text { FK506 (immunosuppressant) } \\
\text { polyketide biosynthesis }\end{array}$ & [77] \\
\hline CYP129A2 & Streptomyces peucetius & Doxorubicin biosynthesis & {$[78,79]$} \\
\hline CYP129A2 (dox A)! & Streptomyces sp. strain C5 & Doxorubicin biosynthesis & {$[80,81]$} \\
\hline CYP131A2 (dnrQ)! & Streptomyces sp. strain C5 & Doxorubicin biosynthesis & {$[80,81]$} \\
\hline CYP140M1(TtnI) * & Streptomyces griseochromogenes & Tautomycetin biosynthesis & [82] \\
\hline CYP151A (AurH)! & Streptomyces thioluteus & Aureothin biosynthesis & [83] \\
\hline CYP154A1 & Streptomyces coelicolor $\mathrm{A} 3(2)$ & $\begin{array}{l}\text { Polyketide synthesis and cyclization } \\
\text { of a cellular dipentaenone }\end{array}$ & {$[84,85]$} \\
\hline
\end{tabular}


Table 4. Cont.

\begin{tabular}{|c|c|c|c|}
\hline P450 & Species & Function & References \\
\hline CYP154B1 & Streptomyces fradiae & Tylosin biosynthesis & {$[54,55]$} \\
\hline CYP154C1 & Streptomyces coelicolor A3(2) & Macrolide biosynthesis & [86] \\
\hline CYP161A2 (PimD)! & Streptomyces natalensis & Pimaricin biosynthesis & {$[88]$} \\
\hline CYP161A3 (AmphL)! & Streptomyces nodosus & Amphotericin biosynthesis & [51] \\
\hline CYP163A1 (NovI)! & Streptomyces spheroids & Novobiocin biosynthesis & [90] \\
\hline CYP163B3 (P450 Sky)! & Streptomyces sp. Acta 2897 & Skyllamycin biosynthesis & [91] \\
\hline CYP170A1 & Streptomyces coelicolor A3(2) & Albaflavenone biosynthesis & [92] \\
\hline CYP170A2 & Streptomyces avermitilis & Albaflavenone biosynthesis & [93] \\
\hline CYP183A1 & Streptomyces avermitilis & Pentalenolactone biosynthesis & {$[96,97]$} \\
\hline CYP244A1 (StaN)! & Streptomyces sp tp-a0274 & Rapamycin biosynthesis & {$[70,71]$} \\
\hline CYP245A1 (StaP)! & Streptomyces sp tp-a0274 & Rapamycin biosynthesis & {$[70,71]$} \\
\hline CYP246A1 & Streptomyces scabiei & Thaxtomin (phytotoxin) biosynthesis & [98] \\
\hline CYP248A1 & Streptomyces thioluteus & Aureothin biosynthesis & [83] \\
\hline
\end{tabular}

Note: For some P450s, protein notations are given in parentheses. These P450s were annotated in this study (indicated with asterisk superscript) and previously (indicated with exclamation mark) [20] by browsing the individual biosynthetic gene-cluster sequences reported in the literature. To enable readers to match the P450s with the published literature, we have provided protein notations in the parentheses. If known, the name of the secondary metabolite of which P450s are involved in production is indicated in the table.

\section{Materials and Methods}

\subsection{Information on Streptomyces Species and Genome Database}

In total, 203 Streptomyces species genomes (permanent and finished draft genomes) available for public use at the Joint Genome Institute Integrated Microbial Genomes and Microbiomes (JGI IMG/M) [99] and Kyoto Encyclopedia of Genes and Genomes (KEGG) [100] were used in this study. The 203 Streptomyces species included 48 Streptomyces species for which P450s and BGCs were annotated previously [20]. For these 48 species, P450 and BGCs data were retrieved from published articles and used in the study [20]. Thus, 155 Streptomyces species were data-mined for P450s and BGCs in this study. Information on the species used in the study is provided in Supplementary Table S1.

\subsection{Genome Data Mining and Identification of P450s}

Identification and annotation of P450s in Streptomyces species were carried out following a method described elsewhere [20-22]. Briefly, each Streptomyces species genome available at JGI IMG/M [99] was searched for P450s using the InterPro code "IPR001128". The hit protein sequences were then searched for the presence of P450 characteristic motifs such as EXXR and CXG [101]. Proteins having one of these motifs were considered pseudo-P450s, and proteins that were short in amino acid length and lacking both motifs as P450 fragments. Neither the pseudo-P450s nor the P450 fragments were considered for further analysis.

\subsection{Allocating Family and Subfamily to P450s}

The hit proteins that were collected were subjected to BLAST analysis against bacterial P450s at the website http://www.p450.unizulu.ac.za/. Based on the International P450 Nomenclature Committee rule [17-19], proteins with a percentage identity greater than $40 \%$ were assigned to the same family as named homolog P450s, and those that had greater than 55\% identity were assigned to the same 
subfamily as named homolog P450s. Proteins that had a percentage identity less than $40 \%$ were assigned to a new family.

\subsection{Streptomyces P450 Phylogenetic Analysis}

Phylogenetic analysis of the Streptomyces P450s was carried out following the method described in the literature [102]. First, the Streptomyces P450 sequences were aligned using the MAFFT v6.864 program with an automatically optimized model option [103], available at the Trex web server [104]. The alignments were then automatically subjected to inference and optimization of the tree by the Trex web server with its embedded weighting procedure, and the best inferred tree was visualized and annotated by iTOL [105].

\subsection{Streptomyces P450 Profile Heat-Maps}

P450 profile heat-maps were generated following a method published previously $[22,27]$ to check the presence and absence of P450s in Streptomyces species. Briefly, a tab-delimited file was imported into Multi-Experiment Viewer (Mev) [106] and hierarchical clustering using a Euclidean distance metric was used to cluster the data. In total, 203 Streptomyces species formed the vertical axis and P450 family numbers formed the horizontal axis. Data were presented as -3 for family absence (green) and 3 for family presence (red).

\subsection{Identification of P450s That Are Part of Secondary Metabolite BGCS}

Secondary metabolite BGCs analysis and identification of P450s that are part of these BGCs were carried out following the procedure mentioned previously [102], with slight modification. For each Streptomyces species genome available at JGI IMG/M, the secondary metabolite BGCs were searched for the presence of P450s. The DNA sequence of BGCs with P450s was collected and formatted to fasta format using PSPad editor (http://www.pspad.com/en/). The fasta-formatted files were then used to identify the type of cluster and most similar known clusters using the Antibiotics and Secondary Metabolite Analysis Shell (anti-SMASH) program [107]. The results obtained were recorded on Excel spreadsheets and represented as species-wise BGCs, type and similar known BGCs, percentage similarity to known BGCs, and P450s that are part of specific BGCs. Some Streptomyces species genome IDs did not pass through anti-SMASH analysis, and thus these species were not included in P450s analysis as part of secondary metabolite BGCs. A list of Streptomyces species subjected to anti-SMASH analysis is presented in Supplementary Table S4.

\subsection{Data Analysis}

All calculations were done following the method described in the literature [23]. The average number of P450s was calculated using the formula: Average number of P450s = Number of P450s/ Number of species. The average number of BGCs was calculated using the formula: Average number of BGCs = Total number of BGCs/Number of species. The percentage of P450s that formed part of BGCs was calculated using the formula: Percentage of P450s part of BGCs $=100 \times$ Number of P450s part of BGCs /Total number of P450s present in species. For comparative analysis of P450s and BGCs, information for bacterial species belonging to the genera Bacillus [22], Mycobacterium [21], and Cyanobacteria [23] was resourced from published articles.

\section{Conclusions}

In the last five decades, research on cytochrome P450 monooxygenases (CYPs/P450s) has mainly focused on their function and structural aspects, with little focus on evolutionary analysis, especially in microbes. The availability of a large number of microbial species genomes gives us an opportunity to focus on exploring the evolutionary aspects of P450s. Because a typical nomenclature system that has been established for P450s, each species genome needs to be data-mined and P450 proteins need 
to be annotated (assigning family and subfamily). In this way, researchers around the world can make use of uniform P450 names. In this study, we therefore annotated a large number of P450s in 203 Streptomyces species and found 38 new P450 families. Some P450 families were found to be bloomed in Streptomyces species even at the subfamily level. Comparative analysis of key P450 features among different bacterial species revealed that Streptomyces species had a greater number of P450s, more secondary metabolite BGCs, and the highest number of P450s as part of BGCs compared to the bacterial species belonging to the genera Bacillus, Mycobacterium, and Cyanobacteria. This further confirmed that the higher the number of $\mathrm{P} 450 \mathrm{~s}$, the higher the secondary metabolite diversity in a species. This was true for Streptomyces species, as large number of P450s were found to be involved in the generation of diverse secondary metabolites. One interesting phenomenon observed was the linkage between a particular P450 family and BGC. This indicates that these BGCs were horizontally transferred among different Streptomyces species. This study is a good addition to the comparative analysis of P450s and BGCs among different bacterial populations. Data presented in the study will serve as a reference for further annotation of P450s in Streptomyces species and other bacterial species. In silico predicted BGCs need to be experimentally validated to assess the secondary metabolites' biological properties.

Supplementary Materials: Supplementary materials can be found at http://www.mdpi.com/1422-0067/21/13/ 4814/s1.

Author Contributions: Conceptualization, K.S.; data curation, F.C.M., T.P., W.C., D.G., J.-H.Y., D.R.N. and K.S.; formal analysis, F.C.M., T.P., W.C., D.G., J.-H.Y., D.R.N. and K.S.; funding acquisition, K.S.; investigation, F.C.M., T.P., W.C., J.-H.Y., D.R.N. and K.S.; methodology, F.C.M., T.P., W.C., D.G., J.-H.Y., D.R.N. and K.S.; project administration, K.S.; resources, K.S.; supervision, K.S.; validation, F.C.M., T.P., W.C., D.G., J.-H.Y., D.R.N. and K.S.; visualization, F.C.M., T.P., W.C., and K.S.; writing-original draft, F.C.M., T.P., W.C., J.-H.Y., D.R.N. and K.S.; writing—review and editing, F.C.M., T.P., W.C., J.-H.Y., D.R.N. and K.S. All authors have read and agreed to the published version of the manuscript.

Funding: The work presented in this article is part of research funded by a National Research Foundation (NRF), South Africa grant awarded to Khajamohiddin Syed (Grant No. 114159), where all the international authors involved in the study are listed as international collaborators. Fanele Cabangile Mnguni thanks the NRF, South Africa for a DST-NRF Innovation Master's Scholarship for the year 2019 (Grant No. 117171). Honours student, Tiara Padayachee, thanks the NRF, South Africa for an honours bursary (Grant No. MND190619448759). Dominik Gront was supported by the National Science Centre, Poland (Grant No. 2018/29/B/ST6/01989). Khajamohiddin Syed expresses sincere gratitude to the University of Zululand Research Committee for funding (Grant No. C686) and for the laboratory facilities.

Acknowledgments: The authors want to thank Barbara Bradley, Pretoria, South Africa for English language editing.

Conflicts of Interest: The authors declare no conflict of interest. The funders had no role in the design of the study, in the collection, analyses, or interpretation of data, in the writing of the manuscript, or in the decision to publish the results.

\section{References}

1. Urlacher, V.B.; Girhard, M. Cytochrome P450 Monooxygenases in Biotechnology and Synthetic Biology. Trends Biotechnol. 2019, 37, 882-897. [CrossRef]

2. Poulos, T.L.; Finzel, B.C.; Howard, A.J. High-resolution crystal structure of cytochrome P450cam. J. Mol. Biol. 1987, 195, 687-700. [CrossRef]

3. Garfinkel, D. Studies on pig liver microsomes. I. Enzymic and pigment composition of different microsomal fractions. Arch. Biochem. Biophys. 1958, 77, 493-509. [CrossRef]

4. Klingenberg, M. Pigments of rat liver microsomes. Arch Biochem. Biophys. 1958, 75, 376-386. [CrossRef]

5. Omura, T. Recollection of the early years of the research on cytochrome P450. Proc. Jpn. Acad. Ser. B Phys. Biol. Sci. 2011, 87, 617-640. [CrossRef] [PubMed]

6. Omura, T.; Sato, R. A new cytochrome in liver microsomes. J. Biol. Chem. 1962, 237, 1375-1376.

7. Nelson, D.R. Cytochrome P450 diversity in the tree of life. Biochim. Biophys. Acta Proteins Proteom. 2018, 1866, 141-154. [CrossRef] 
8. Lamb, D.C.; Follmer, A.H.; Goldstone, J.V.; Nelson, D.R.; Warillow, A.G.; Price, C.L.; True, M.Y.; Kelly, S.L.; Poulos, T.L.; Stegeman, J.J. On the occurrence of cytochrome P450 in viruses. Proc. Natl. Acad. Sci. USA 2019, 116, 12343-12352. [CrossRef]

9. Lepesheva, G.I.; Hargrove, T.Y.; Kleshchenko, Y.; Nes, W.D.; Villalta, F.; Waterman, M.R. CYP51: A major drug target in the cytochrome P450 superfamily. Lipids 2008, 43, 1117-1125. [CrossRef]

10. Kelly, S.L.; Kelly, D.E. Microbial cytochromes P450: Biodiversity and biotechnology. Where do cytochromes P450 come from, what do they do and what can they do for us? Philos. Trans. R. Soc. London Ser. B Biol. Sci. 2013, 368, 20120476. [CrossRef]

11. Jawallapersand, P.; Mashele, S.S.; Kovacic, L.; Stojan, J.; Komel, R.; Pakala, S.B.; Krasevec, N.; Syed, K. Cytochrome P450 monooxygenase CYP53 family in fungi: Comparative structural and evolutionary analysis and its role as a common alternative anti-fungal drug target. PLoS ONE 2014, 9, e107209. [CrossRef]

12. Ziniel, P.D.; Karumudi, B.; Barnard, A.H.; Fisher, E.M.; Thatcher, G.R.; Podust, L.M.; Williams, D.L. The Schistosoma mansoni Cytochrome P450 (CYP3050A1) Is Essential for Worm Survival and Egg Development. PLoS Negl. Trop. Dis. 2015, 9, e0004279. [CrossRef]

13. Ortiz de Montellano, P.R. Potential drug targets in the Mycobacterium tuberculosis cytochrome P450 system. J. Inorg. Biochem. 2018, 180, 235-245. [CrossRef]

14. Podust, L.M.; Sherman, D.H. Diversity of P450 enzymes in the biosynthesis of natural products. Nat. Prod. Rep. 2012, 29, 1251-1266. [CrossRef]

15. Greule, A.; Stok, J.E.; De Voss, J.J.; Cryle, M.J. Unrivalled diversity: The many roles and reactions of bacterial cytochromes P450 in secondary metabolism. Nat. Prod. Rep. 2018, 35, 757-791. [CrossRef]

16. Rudolf, J.D.; Chang, C.Y.; Ma, M.; Shen, B. Cytochromes P450 for natural product biosynthesis in Streptomyces: Sequence, structure, and function. Nat. Prod. Rep. 2017, 34, 1141-1172. [CrossRef]

17. Nelson, D.R.; Kamataki, T.; Waxman, D.J.; Guengerich, F.P.; Estabrook, R.W.; Feyereisen, R.; Gonzalez, F.J.; Coon, M.J.; Gunsalus, I.C.; Gotoh, O.; et al. The P450 superfamily: Update on new sequences, gene mapping, accession numbers, early trivial names of enzymes, and nomenclature. DNA Cell Biol. 1993, 12, 1-51. [CrossRef]

18. Nelson, D.R. Cytochrome P450 nomenclature. Methods Mol. Biol. (Clifton NJ) 1998, 107, 15-24. [CrossRef]

19. Nelson, D.R. Cytochrome P450 nomenclature, 2004. Methods Mol. Biol. (Clifton NJ) 2006, 320, 1-10. [CrossRef]

20. Senate, L.M.; Tjatji, M.P.; Pillay, K.; Chen, W.; Zondo, N.M.; Syed, P.R.; Mnguni, F.C.; Chiliza, Z.E.; Bamal, H.D.; Karpoormath, R. Similarities, variations, and evolution of cytochrome P450s in Streptomyces versus Mycobacterium. Sci. Rep. 2019, 9, 3962. [CrossRef]

21. Parvez, M.; Qhanya, L.B.; Mthakathi, N.T.; Kgosiemang, I.K.; Bamal, H.D.; Pagadala, N.S.; Xie, T.; Yang, H.; Chen, H.; Theron, C.W.; et al. Molecular evolutionary dynamics of cytochrome P450 monooxygenases across kingdoms: Special focus on mycobacterial P450s. Sci. Rep. 2016, 6, 33099. [CrossRef]

22. Mthethwa, B.; Chen, W.; Ngwenya, M.; Kappo, A.; Syed, P.; Karpoormath, R.; Yu, J.-H.; Nelson, D.; Syed, K. Comparative analyses of cytochrome P450s and those associated with secondary metabolism in Bacillus species. Int. J. Mol. Sci. 2018, 19, 3623. [CrossRef]

23. Khumalo, M.J.N.; Padayachee, T.; Chen, W.; Yu, J.-H.; Nelson, D.; Syed, K. Comprehensive analyses of cytochrome $\mathrm{P} 450$ monoxygenases and secondary metabolite biosynthetic gene clusters in Cyanobacteria. Int. J. Mol. Sci. 2020, 21, 656. [CrossRef]

24. Syed, K.; Shale, K.; Pagadala, N.S.; Tuszynski, J. Systematic identification and evolutionary analysis of catalytically versatile cytochrome P450 monooxygenase families enriched in model basidiomycete fungi. PLOS ONE 2014, 9, e86683. [CrossRef]

25. Kgosiemang, I.K.R.; Syed, K.; Mashele, S.S. Comparative genomics and evolutionary analysis of cytochrome P450 monooxygenases in fungal subphylum Saccharomycotina. J. Pure Appl. Microbiol. 2014, 8, 12.

26. Sello, M.M.; Jafta, N.; Nelson, D.R.; Chen, W.; Yu, J.H.; Parvez, M.; Kgosiemang, I.K.; Monyaki, R.; Raselemane, S.C.; Qhanya, L.B.; et al. Diversity and evolution of cytochrome P450 monooxygenases in Oomycetes. Sci. Rep. 2015, 5, 11572. [CrossRef]

27. Akapo, O.O.; Padayachee, T.; Chen, W.; Kappo, A.P.; Yu, J.H.; Nelson, D.R.; Syed, K. Distribution and Diversity of Cytochrome P450 Monooxygenases in the Fungal Class Tremellomycetes. Int. J. Mol. Sci. 2019, 20, 2889. [CrossRef]

28. de Lima Procópio, R.E.; da Silva, I.R.; Martins, M.K.; de Azevedo, J.L.; de Araújo, J.M. Antibiotics produced by Streptomyces. Braz. J. Infect. Dis. 2012, 16, 466-471. [CrossRef] 
29. Hwang, K.-S.; Kim, H.U.; Charusanti, P.; Palsson, B.Ø.; Lee, S.Y. Systems biology and biotechnology of Streptomyces species for the production of secondary metabolites. Biotechnol. Adv. 2014, 32, 255-268. [CrossRef]

30. Harir, M.; Bendif, H.; Bellahcene, M.; Fortas, Z.; Pogni, R. Streptomyces Secondary Metabolites. In Basic Biology and Applications of Actinobacteria; IntechOpen: London, UK, 2018; pp. 99-122. [CrossRef]

31. Cho, M.-A.; Han, S.; Lim, Y.-R.; Kim, V.; Kim, H.; Kim, D. Streptomyces Cytochrome P450 Enzymes and Their Roles in the Biosynthesis of Macrolide Therapeutic Agents. Biomol. Ther. 2019, 27, 127. [CrossRef]

32. Moody, S.C.; Loveridge, E.J. CYP105-diverse structures, functions and roles in an intriguing family of enzymes in Streptomyces. J. Appl. Microbiol. 2014, 117, 1549-1563. [CrossRef]

33. Lamb, D.C.; Waterman, M.R.; Zhao, B. Streptomyces cytochromes P450: Applications in drug metabolism. Expert Opin. Drug Metab. Toxicol. 2013, 9, 1279-1294. [CrossRef]

34. Feyereisen, R. Insect CYP genes and P450 enzymes. In Insect Molecular Biology and Biochemistry; Elsevier: Amsterdam, The Netherlands, 2012; pp. 236-316.

35. Qhanya, L.B.; Matowane, G.; Chen, W.; Sun, Y.; Letsimo, E.M.; Parvez, M.; Yu, J.H.; Mashele, S.S.; Syed, K. Genome-wide annotation and comparative analysis of cytochrome P450 monooxygenases in Basidiomycete biotrophic plant pathogens. PLoS ONE 2015, 10, e0142100. [CrossRef]

36. Ngwenya, M.L.; Chen, W.; Basson, A.K.; Shandu, J.S.; Yu, J.H.; Nelson, D.R.; Syed, K. Blooming of unusual cytochrome P450s by tandem duplication in the pathogenic fungus Conidiobolus coronatus. Int. J. Mol. Sci. 2018, 19, 1711. [CrossRef]

37. Tran, P.N.; Yen, M.R.; Chiang, C.Y.; Lin, H.C.; Chen, P.Y. Detecting and prioritizing biosynthetic gene clusters for bioactive compounds in bacteria and fungi. Appl. Microbiol. Biotechnol. 2019, 103, 3277-3287. [CrossRef]

38. Zhao, B.; Lamb, D.C.; Lei, L.; Kelly, S.L.; Yuan, H.; Hachey, D.L.; Waterman, M.R. Different binding modes of two flaviolin substrate molecules in cytochrome P450 158A1 (CYP158A1) compared to CYP158A2. Biochemistry 2007, 46, 8725-8733. [CrossRef]

39. Yu, F.; Li, M.; Xu, C.; Wang, Z.; Zhou, H.; Yang, M.; Chen, Y.; Tang, L.; He, J. Structural insights into the mechanism for recognizing substrate of the cytochrome P450 enzyme TxtE. PLoS ONE 2013, 8, e81526. [CrossRef]

40. Janocha, S.; Zapp, J.; Hutter, M.; Kleser, M.; Bohlmann, J.; Bernhardt, R. Resin acid conversion with CYP105A1: An enzyme with potential for the production of pharmaceutically relevant diterpenoids. Chembiochem 2013, 14, 467-473. [CrossRef]

41. Watanabe, I.; Nara, F.; Serizawa, N. Cloning, characterization and expression of the gene encoding cytochrome P-450sca-in2 from Streptomyces carbophilus involved in production of pravastatin, a specific HMG-CoA reductase inhibitor. Gene 1995, 163, 81-85. [CrossRef]

42. Kudo, F.; Motegi, A.; Mizoue, K.; Eguchi, T. Cloning and characterization of the biosynthetic gene cluster of 16-membered macrolide antibiotic FD-891: Involvement of a dual functional cytochrome P450 monooxygenase catalyzing epoxidation and hydroxylation. Chembiochem 2010, 11, 1574-1582. [CrossRef]

43. Kataoka, T.; Yamada, A.; Bando, M.; Honma, T.; Mizoue, K.; Nagai, K. FD-891, a structural analogue of concanamycin A that does not affect vacuolar acidification or perforin activity, yet potently prevents cytotoxic T lymphocyte-mediated cytotoxicity through the blockage of conjugate formation. Immunology 2000, 100, 170-177. [CrossRef]

44. Xu, L.H.; Fushinobu, S.; Takamatsu, S.; Wakagi, T.; Ikeda, H.; Shoun, H. Regio- and stereospecificity of filipin hydroxylation sites revealed by crystal structures of cytochrome P450 105P1 and 105D6 from Streptomyces avermitilis. J. Biol. Chem. 2010, 285, 16844-16853. [CrossRef] [PubMed]

45. Takamatsu, S.; Xu, L.H.; Fushinobu, S.; Shoun, H.; Komatsu, M.; Cane, D.E.; Ikeda, H. Pentalenic acid is a shunt metabolite in the biosynthesis of the pentalenolactone family of metabolites: Hydroxylation of 1-deoxypentalenic acid mediated by CYP105D7 (SAV_7469) of Streptomyces avermitilis. J. Antibiot. 2011, 64, 65-71. [CrossRef]

46. Jungmann, V.; Molnar, I.; Hammer, P.E.; Hill, D.S.; Zirkle, R.; Buckel, T.G.; Buckel, D.; Ligon, J.M.; Pachlatko, J.P. Biocatalytic conversion of avermectin to 4"-oxo-avermectin: Characterization of biocatalytically active bacterial strains and of cytochrome p450 monooxygenase enzymes and their genes. Appl. Environ. Microbiol. 2005, 71, 6968-6976. [CrossRef] 
47. Yunt, Z.; Reinhardt, K.; Li, A.; Engeser, M.; Dahse, H.M.; Gutschow, M.; Bruhn, T.; Bringmann, G.; Piel, J. Cleavage of four carbon-carbon bonds during biosynthesis of the griseorhodin a spiroketal pharmacophore. J. Am. Chem. Soc. 2009, 131, 2297-2305. [CrossRef]

48. Rodriguez, A.M.; Olano, C.; Mendez, C.; Hutchinson, C.R.; Salas, J.A. A cytochrome P450-like gene possibly involved in oleandomycin biosynthesis by Streptomyces antibioticus. FEMS Microbiol. Lett. 1995, 127, 117-120. [CrossRef]

49. Shrestha, P.; Oh, T.J.; Liou, K.; Sohng, J.K. Cytochrome P450 (CYP105F2) from Streptomyces peucetius and its activity with oleandomycin. Appl. Microbiol. Biotechnol. 2008, 79, 555-562. [CrossRef]

50. Aparicio, J.F.; Fouces, R.; Mendes, M.V.; Olivera, N.; Martin, J.F. A complex multienzyme system encoded by five polyketide synthase genes is involved in the biosynthesis of the 26-membered polyene macrolide pimaricin in Streptomyces natalensis. Chem. Biol. 2000, 7, 895-905. [CrossRef]

51. Caffrey, P.; Lynch, S.; Flood, E.; Finnan, S.; Oliynyk, M. Amphotericin biosynthesis in Streptomyces nodosus: Deductions from analysis of polyketide synthase and late genes. Chem. Biol. 2001, 8, 713-723. [CrossRef]

52. Agarwal, P.K.; Agarwal, P.; Reddy, M.K.; Sopory, S.K. Role of DREB transcription factors in abiotic and biotic stress tolerance in plants. Plant Cell Rep. 2006, 25, 1263-1274. [CrossRef]

53. Lauer, B.; Russwurm, R.; Schwarz, W.; Kalmanczhelyi, A.; Bruntner, C.; Rosemeier, A.; Bormann, C. Molecular characterization of co-transcribed genes from Streptomyces tendae Tu901 involved in the biosynthesis of the peptidyl moiety and assembly of the peptidyl nucleoside antibiotic nikkomycin. Mol. Gen. Genet. MGG 2001, 264, 662-673. [CrossRef]

54. Merson-Davies, L.A.; Cundliffe, E. Analysis of five tylosin biosynthetic genes from the tyllBA region of the Streptomyces fradiae genome. Mol. Microbiol. 1994, 13, 349-355. [CrossRef] [PubMed]

55. Fouces, R.; Mellado, E.; Diez, B.; Barredo, J.L. The tylosin biosynthetic cluster from Streptomyces fradiae: Genetic organization of the left region. Microbiology 1999, 145 Pt 4, 855-868. [CrossRef] [PubMed]

56. Ward, S.L.; Hu, Z.; Schirmer, A.; Reid, R.; Revill, W.P.; Reeves, C.D.; Petrakovsky, O.V.; Dong, S.D.; Katz, L. Chalcomycin biosynthesis gene cluster from Streptomyces bikiniensis: Novel features of an unusual ketolide produced through expression of the chm polyketide synthase in Streptomyces fradiae. Antimicrob. Agents Chemother. 2004, 48, 4703-4712. [CrossRef] [PubMed]

57. Reading, C.; Cole, M. Clavulanic acid: A beta-lactamase-inhibiting beta-lactam from Streptomyces clavuligerus. Antimicrob. Agents Chemother. 1977, 11, 852-857. [CrossRef]

58. Lim, Y.R.; Hong, M.K.; Kim, J.K.; Doan, T.T.; Kim, D.H.; Yun, C.H.; Chun, Y.J.; Kang, L.W.; Kim, D. Crystal structure of cytochrome P450 CYP105N1 from Streptomyces coelicolor, an oxidase in the coelibactin siderophore biosynthetic pathway. Arch Biochem. Biophys. 2012, 528, 111-117. [CrossRef]

59. Zhao, B.; Moody, S.C.; Hider, R.C.; Lei, L.; Kelly, S.L.; Waterman, M.R.; Lamb, D.C. Structural analysis of cytochrome P450 105N1 involved in the biosynthesis of the zincophore, coelibactin. Int. J. Mol. Sci. 2012, 13, 8500-8513. [CrossRef]

60. Li, T.; Ni, S.; Jia, C.; Wang, H.; Sun, G.; Wu, L.; Gan, M.; Shan, G.; He, W.; Lin, L.; et al. Identification of 4,5-dihydro-4-hydroxygeldanamycins as shunt products of geldanamycin biosynthesis. J. Nat. Prod. 2012, 75, 1480-1484. [CrossRef]

61. Palaniappan, N.; Kim, B.S.; Sekiyama, Y.; Osada, H.; Reynolds, K.A. Enhancement and selective production of phoslactomycin B, a protein phosphatase II a inhibitor, through identification and engineering of the corresponding biosynthetic gene cluster. J. Biol. Chem. 2003, 278, 35552-35557. [CrossRef]

62. Niraula, N.P.; Kanth, B.K.; Sohng, J.K.; Oh, T.J. Hydrogen peroxide-mediated dealkylation of 7-ethoxycoumarin by cytochrome P450 (CYP107AJ1) from Streptomyces peucetius ATCC27952. Enzym. Microb. Technol. 2011, 48, 181-186. [CrossRef]

63. Shafiee, A.; Hutchinson, C.R. Macrolide antibiotic biosynthesis: Isolation and properties of two forms of 6-deoxyerythronolide B hydroxylase from Saccharopolyspora erythraea (Streptomyces erythreus). Biochemistry 1987, 26, 6204-6210. [CrossRef]

64. Stassi, D.; Donadio, S.; Staver, M.J.; Katz, L. Identification of a Saccharopolyspora erythraea gene required for the final hydroxylation step in erythromycin biosynthesis. J. Bacteriol. 1993, 175, 182-189. [CrossRef] [PubMed]

65. Zhang, H.; Chen, J.; Wang, H.; Xie, Y.; Ju, J.; Yan, Y.; Zhang, H. Structural analysis of HmtT and HmtN involved in the tailoring steps of himastatin biosynthesis. FEBS Lett. 2013, 587, 1675-1680. [CrossRef] 
66. Ma, J.; Wang, Z.; Huang, H.; Luo, M.; Zuo, D.; Wang, B.; Sun, A.; Cheng, Y.Q.; Zhang, C.; Ju, J. Biosynthesis of himastatin: Assembly line and characterization of three cytochrome P450 enzymes involved in the post-tailoring oxidative steps. Angew. Chem. (Int. Ed. Engl.) 2011, 50, 7797-7802. [CrossRef]

67. Arisawa, A.; Tsunekawa, H.; Okamura, K.; Okamoto, R. Nucleotide sequence analysis of the carbomycin biosynthetic genes including the 3-O-acyltransferase gene from Streptomyces thermotolerans. Biosci. Biotechnol. Biochem. 1995, 59, 582-588. [CrossRef] [PubMed]

68. Carlson, J.C.; Fortman, J.L.; Anzai, Y.; Li, S.; Burr, D.A.; Sherman, D.H. Identification of the tirandamycin biosynthetic gene cluster from Streptomyces sp. 307-9. Chembiochem 2010, 11, 564-572. [CrossRef]

69. Carlson, J.C.; Li, S.; Gunatilleke, S.S.; Anzai, Y.; Burr, D.A.; Podust, L.M.; Sherman, D.H. Tirandamycin biosynthesis is mediated by co-dependent oxidative enzymes. Nat. Chem. 2011, 3, 628-633. [CrossRef] [PubMed]

70. Aparicio, J.F.; Molnar, I.; Schwecke, T.; Konig, A.; Haydock, S.F.; Khaw, L.E.; Staunton, J.; Leadlay, P.F. Organization of the biosynthetic gene cluster for rapamycin in Streptomyces hygroscopicus: Analysis of the enzymatic domains in the modular polyketide synthase. Gene 1996, 169, 9-16. [CrossRef]

71. Molnar, I.; Aparicio, J.F.; Haydock, S.F.; Khaw, L.E.; Schwecke, T.; Konig, A.; Staunton, J.; Leadlay, P.F. Organisation of the biosynthetic gene cluster for rapamycin in Streptomyces hygroscopicus: Analysis of genes flanking the polyketide synthase. Gene 1996, 169, 1-7. [CrossRef]

72. Huang, S.; Bjornsti, M.-A.; Houghton, P.J. Rapamycins: Mechanisms of action and cellular resistance. Cancer Biol. Ther. 2003, 2, 222-232. [CrossRef]

73. Sherman, D.H.; Li, S.; Yermalitskaya, L.V.; Kim, Y.; Smith, J.A.; Waterman, M.R.; Podust, L.M. The structural basis for substrate anchoring, active site selectivity, and product formation by P450 PikC from Streptomyces venezuelae. J. Biol. Chem. 2006, 281, 26289-26297. [CrossRef] [PubMed]

74. Kong, R.; Liu, X.; Su, C.; Ma, C.; Qiu, R.; Tang, L. Elucidation of the biosynthetic gene cluster and the post-PKS modification mechanism for fostriecin in Streptomyces pulveraceus. Chem. Biol. 2013, 20, 45-54. [CrossRef] [PubMed]

75. Han, S.; Pham, T.V.; Kim, J.H.; Lim, Y.R.; Park, H.G.; Cha, G.S.; Yun, C.H.; Chun, Y.J.; Kang, L.W.; Kim, D. Functional characterization of CYP107W1 from Streptomyces avermitilis and biosynthesis of macrolide oligomycin A. Arch Biochem. Biophys. 2015, 575, 1-7. [CrossRef] [PubMed]

76. Han, S.; Pham, T.V.; Kim, J.H.; Lim, Y.R.; Park, H.G.; Cha, G.S.; Yun, C.H.; Chun, Y.J.; Kang, L.W.; Kim, D. Structural Analysis of the Streptomyces avermitilis CYP107W1-Oligomycin A Complex and Role of the Tryptophan 178 Residue. Mol. Cells 2016, 39, 211-216. [CrossRef] [PubMed]

77. Chen, D.; Zhang, Q.; Zhang, Q.; Cen, P.; Xu, Z.; Liu, W. Improvement of FK506 production in Streptomyces tsukubaensis by genetic enhancement of the supply of unusual polyketide extender units via utilization of two distinct site-specific recombination systems. Appl. Environ. Microbiol. 2012, 78, 5093-5103. [CrossRef]

78. Lomovskaya, N.; Otten, S.L.; Doi-Katayama, Y.; Fonstein, L.; Liu, X.C.; Takatsu, T.; Inventi-Solari, A.; Filippini, S.; Torti, F.; Colombo, A.L.; et al. Doxorubicin overproduction in Streptomyces peucetius: Cloning and characterization of the dnrU ketoreductase and $\mathrm{dnrV}$ genes and the doxA cytochrome P-450 hydroxylase gene. J. Bacteriol. 1999, 181, 305-318. [CrossRef]

79. Madduri, K.; Hutchinson, C.R. Functional characterization and transcriptional analysis of a gene cluster governing early and late steps in daunorubicin biosynthesis in Streptomyces peucetius. J. Bacteriol. 1995, 177, 3879-3884. [CrossRef]

80. Dickens, M.L.; Priestley, N.D.; Strohl, W.R. In vivo and in vitro bioconversion of epsilon-rhodomycinone glycoside to doxorubicin: Functions of DauP, DauK, and DoxA. J. Bacteriol. 1997, 179, 2641-2650. [CrossRef]

81. Walczak, R.J.; Dickens, M.L.; Priestley, N.D.; Strohl, W.R. Purification, properties, and characterization of recombinant Streptomyces sp. strain C5 DoxA, a cytochrome P-450 catalyzing multiple steps in doxorubicin biosynthesis. J. Bacteriol. 1999, 181, 298-304. [CrossRef]

82. Li, W.; Luo, Y.; Ju, J.; Rajski, S.R.; Osada, H.; Shen, B. Characterization of the tautomycetin biosynthetic gene cluster from Streptomyces griseochromogenes provides new insight into dialkylmaleic anhydride biosynthesis. J. Nat. Prod. 2009, 72, 450-459. [CrossRef]

83. Zocher, G.; Richter, M.E.; Mueller, U.; Hertweck, C. Structural fine-tuning of a multifunctional cytochrome P450 monooxygenase. J. Am. Chem. Soc. 2011, 133, 2292-2302. [CrossRef] [PubMed] 
84. Podust, L.M.; Bach, H.; Kim, Y.; Lamb, D.C.; Arase, M.; Sherman, D.H.; Kelly, S.L.; Waterman, M.R. Comparison of the 1.85 A structure of CYP154A1 from Streptomyces coelicolor A3(2) with the closely related CYP154C1 and CYPs from antibiotic biosynthetic pathways. Protein Sci. Publ. Protein Soc. 2004, 13, 255-268. [CrossRef] [PubMed]

85. Cheng, Q.; Lamb, D.C.; Kelly, S.L.; Lei, L.; Guengerich, F.P. Cyclization of a cellular dipentaenone by Streptomyces coelicolor cytochrome P450 154A1 without oxidation/reduction. J. Am. Chem. Soc. 2010, 132, 15173-15175. [CrossRef] [PubMed]

86. Podust, L.M.; Kim, Y.; Arase, M.; Neely, B.A.; Beck, B.J.; Bach, H.; Sherman, D.H.; Lamb, D.C.; Kelly, S.L.; Waterman, M.R. The 1.92-A structure of Streptomyces coelicolor A3(2) CYP154C1. A new monooxygenase that functionalizes macrolide ring systems. J. Biol. Chem. 2003, 278, 12214-12221. [CrossRef] [PubMed]

87. Zhao, B.; Bellamine, A.; Lei, L.; Waterman, M.R. The role of Ile87 of CYP158A2 in oxidative coupling reaction. Arch Biochem. Biophys. 2012, 518, 127-132. [CrossRef] [PubMed]

88. Mendes, M.V.; Anton, N.; Martin, J.F.; Aparicio, J.F. Characterization of the polyene macrolide P450 epoxidase from Streptomyces natalensis that converts de-epoxypimaricin into pimaricin. Biochem. J. 2005, 386, 57-62. [CrossRef]

89. Xie, Z.; Niu, G.; Li, R.; Liu, G.; Tan, H. Identification and characterization of sanH and sanI involved in the hydroxylation of pyridyl residue during nikkomycin biosynthesis in Streptomyces ansochromogenes. Curr. Microbiol. 2007, 55, 537-542. [CrossRef]

90. Chen, H.; Walsh, C.T. Coumarin formation in novobiocin biosynthesis: Beta-hydroxylation of the aminoacyl enzyme tyrosyl-S-NovH by a cytochrome P450 NovI. Chem. Biol. 2001, 8, 301-312. [CrossRef]

91. Uhlmann, S.; Süssmuth, R.D.; Cryle, M.J. Cytochrome p450sky interacts directly with the nonribosomal peptide synthetase to generate three amino acid precursors in skyllamycin biosynthesis. ACS Chem. Biol. 2013, 8, 2586-2596. [CrossRef]

92. Zhao, B.; Lei, L.; Vassylyev, D.G.; Lin, X.; Cane, D.E.; Kelly, S.L.; Yuan, H.; Lamb, D.C.; Waterman, M.R. Crystal structure of albaflavenone monooxygenase containing a moonlighting terpene synthase active site. J. Biol. Chem. 2009, 284, 36711-36719. [CrossRef]

93. Takamatsu, S.; Lin, X.; Nara, A.; Komatsu, M.; Cane, D.E.; Ikeda, H. Characterization of a silent sesquiterpenoid biosynthetic pathway in Streptomyces avermitilis controlling epi-isozizaene albaflavenone biosynthesis and isolation of a new oxidized epi-isozizaene metabolite. Microb. Biotechnol. 2011, 4, 184-191. [CrossRef] [PubMed]

94. Moody, S.C.; Zhao, B.; Lei, L.; Nelson, D.R.; Mullins, J.G.; Waterman, M.R.; Kelly, S.L.; Lamb, D.C. Investigating conservation of the albaflavenone biosynthetic pathway and CYP170 bifunctionality in streptomycetes. FEBS J. 2012, 279, 1640-1649. [CrossRef] [PubMed]

95. Ikeda, H.; Omura, S. Avermectin Biosynthesis. Chem. Rev. 1997, 97, 2591-2610. [CrossRef] [PubMed]

96. Lamb, D.C.; Ikeda, H.; Nelson, D.R.; Ishikawa, J.; Skaug, T.; Jackson, C.; Omura, S.; Waterman, M.R.; Kelly, S.L. Cytochrome 450 complement (CYPome) of the avermectin-producer Streptomyces avermitilis and comparison to that of Streptomyces coelicolor A3(2). Biochem. Biophys. Res. Commun. 2003, 307, 610-619. [CrossRef]

97. Tetzlaff, C.N.; You, Z.; Cane, D.E.; Takamatsu, S.; Omura, S.; Ikeda, H. A gene cluster for biosynthesis of the sesquiterpenoid antibiotic pentalenolactone in Streptomyces avermitilis. Biochemistry 2006, 45, 6179-6186. [CrossRef] [PubMed]

98. Healy, F.G.; Krasnoff, S.B.; Wach, M.; Gibson, D.M.; Loria, R. Involvement of a cytochrome P450 monooxygenase in thaxtomin A biosynthesis by Streptomyces acidiscabies. J. Bacteriol. 2002, 184, 2019-2029. [CrossRef]

99. Markowitz, V.M.; Chen, I.-M.A.; Palaniappan, K.; Chu, K.; Szeto, E.; Grechkin, Y.; Ratner, A.; Jacob, B.; Huang, J.; Williams, P. IMG: The integrated microbial genomes database and comparative analysis system. Nucleic Acids Res. 2011, 40, D115-D122. [CrossRef]

100. Kanehisa, M.; Sato, Y.; Furumichi, M.; Morishima, K.; Tanabe, M. New approach for understanding genome variations in KEGG. Nucleic Acids Res. 2019, 47, D590-D595. [CrossRef]

101. Syed, K.; Mashele, S.S. Comparative analysis of P450 signature motifs EXXR and CXG in the large and diverse kingdom of fungi: Identification of evolutionarily conserved amino acid patterns characteristic of P450 family. PLoS ONE 2014, 9, e95616. [CrossRef] 
102. Syed, P.R.; Chen, W.; Nelson, D.R.; Kappo, A.P.; Yu, J.H.; Karpoormath, R.; Syed, K. Cytochrome P450 Monooxygenase CYP139 Family Involved in the Synthesis of Secondary Metabolites in 824 Mycobacterial Species. Int. J. Mol. Sci. 2019, 20, 2690. [CrossRef]

103. Katoh, K.; Kuma, K.-I.; Toh, H.; Miyata, T. MAFFT version 5: Improvement in accuracy of multiple sequence alignment. Nucleic Acids Res. 2005, 33, 511-518. [CrossRef] [PubMed]

104. Boc, A.; Diallo, A.B.; Makarenkov, V. T-REX: A web server for inferring, validating and visualizing phylogenetic trees and networks. Nucleic Acids Res. 2012, 40, W573-W579. [CrossRef] [PubMed]

105. Letunic, I.; Bork, P. Interactive Tree Of Life (iTOL) v4: Recent updates and new developments. Nucleic Acids Res. 2019, 47, W256-W259. [CrossRef] [PubMed]

106. Howe, E.; Holton, K.; Nair, S.; Schlauch, D.; Sinha, R.; Quackenbush, J. Mev: Multiexperiment viewer. In Biomedical Informatics for Cancer Research; Springer: Berlin/Heidelberg, Germany, 2010; pp. 267-277.

107. Blin, K.; Wolf, T.; Chevrette, M.G.; Lu, X.; Schwalen, C.J.; Kautsar, S.A.; Suarez Duran, H.G.; de Los Santos, E.L.C.; Kim, H.U.; Nave, M.; et al. antiSMASH 4.0-improvements in chemistry prediction and gene cluster boundary identification. Nucleic Acids Res. 2017, 45, W36-W41. [CrossRef] [PubMed]

(C) 2020 by the authors. Licensee MDPI, Basel, Switzerland. This article is an open access article distributed under the terms and conditions of the Creative Commons Attribution (CC BY) license (http://creativecommons.org/licenses/by/4.0/). 